\title{
Further Studies on the Cytology of the Ascus.
}

BY

\author{
H. C. I. FRASER, D.Sc. (Lond.), F.L.S. \\ Ilead of the Department of Botany, Birkbeck College, London;
}

AND

W. E. ST. JOHN BROOKS, B.A.

Assistant, Department of Botany, British Museum.

\section{With Plates XXXIX and XL, and a Figure in the Text.}

RECENT investigations $(8,9)$ have shown that the three nuclear 1 divisions in the ascus comprise two processes, of chromosome reduction. Such a state of affairs is necessarily correlated with the occurrence of two nuclear fusions, and it has therefore seemed to us worth while to study the ascus divisions in forms in which fusion had already been reported in both the ascogonium and ascus.

For this purpose Humaria gramulata, Quel., Ascobolus furfuraceus, Pers., and Lachnea stercorea, Pers., were selected ; in each of these reduced fertilization has been observed in the ascogonium, and in each a second and subsequent fusion takes place in the ascus.

\section{Methods.}

The apothecia were fixed in various strengths of Flemming's and of Hermann's fluid and were embedded in the usual way. Sections were stained with Flemming's triple stain or with the iron haematoxylin of Heidenhain. In the latter case material was counter-stained with saturated solution of erythrosin in clove oil, or with Licht Grün similarly prepared. The latter substance, though unsatisfactory in aqueous solution, forms a very delicate cellulose stain when dissolved in clove oil ; in phanerogamic material it differentiates the cell-wall, leaving the middle lamella unstained.

We are indebted to the Government Grant Committee of the Royal Society for the use of a Zeiss $2 \mathrm{~mm}$. I.40 apochromatic oil-immersion objective, a Swift panaplanatic condenser, and various other lenses. 


\section{HUMARIA GRANULATA.}

Fertilization in Humaria gramulata was studied by Professor V. H. Blackman and one of ourselves (2) in I906; no antheridium was observed, but the female nuclei were seen to fuse in pairs in the ascogonium.

The first division in the ascus is characterized by synaptic stages (Pl. XXXIX, Figs. 4, 5), and the chromosomes assume the various forms (V's, Y's, X's, \&c.) which indicate the occurrence of meiotic reduction (Figs. $6,7)$; the material, however, did not lend itself to the discrimination of the finer details of this process. The number of chromosomes on the spindle in the metaphase is eight (Fig. 8), and eight travel to each pole (Fig. 9).

In the second division four chromosomes appear (Fig. Jo), and the same number is distributed to each of the daughter-nuclei (Fig. I I). The third division closely resembles the second, and the number of chromosomes is the same (Figs. I2, I3). A brachymeiotic reduction is thus accomplished, the number of chromosomes present in the heterotype telophase is reduced to half, and the gametophytic number becomes evident. We did not satisfy ourselves of the occurrence of contraction phases in connexion with either the second or the third mitosis, for in Humaria gramulata no definite spireme was demonstrated at this stage, but the stainable material was aggregated in an irregular mass occupying part, usually the centre, of the nuclear area.

In Humaria granulata the divisions in the ascogenous hypha are very clear, and we succeeded in counting the number of chromosomes here also. Four are present in the early metaphase (Fig. I), and in the anaphase four are found travelling to each pole. Four is the gametophytic number in this fungus, and we therefore at first inferred that we were dealing with a specimen in which fertilization had not occurred, or in which, as Claussen (3) suggests, mere nuclear approximation and not fusion had taken place in the ascogonium.

Not only, however, has the fusion of sexual nuclei been already observed in a number of ascogonia (Blackman and Fraser (2)), but the ascus itself shows two reduction stages : first, the synapses and gemini which are generally accepted as characterizing meiosis, and, secondly, in a subsequent division, the numerical change from eight chromosomes to four. Consequently, as the number of our examples of division in the ascogenous hyphae increased, we were led to the conclusion that in Humaria gramulata, as in Phyllactinia (Harper (12)), and in certain other organisms the chromosomes become associated in pairs at the time of fertilization, and the sporophyte therefore shows four bivalent instead of eight univalent chromosomes. ${ }^{1}$

${ }^{1}$ It is perhaps worth noting that the only other possible interpretation, that which denies the fusion in the ascogonium, must also discard the meiotic reduction, for the change in the number 
In several of the divisions observed in Humaria gramulata an elongated, deeply staining body is present (Figs. 8, I0) extending from the group of chromosomes to the nucleolus or to one of the larger of the granules which lie around the nuclear area. The appearance suggests that stainable material is passing towards the chromosomes from the nucleolus, and the irregular or vacuolate character of the latter (Fig. 8) is frequently in keeping with such an inference. Spore-formation was not studied in detail in Humaria granulata, but such observations as we have made accord well with the description given of this process in Lachnea stercorea.

\section{ASCOBOLUS FURFURACEUS.}

Nuclear fusion was observed by E. J. Welsford (19) in 1907 in the ascogenous cell of this species. In the same year the ascus was studied by Dangeard (4), who described eight chromosomes in the first mitosis, and four in the two which succeed it. When the latter account came to our notice our work on Ascobolus furfuraceus was already begun, and we are now able to confirm Dangeard's observations.

The heterotype prophases are here well marked, and it is possible to recognize the synaptic stage (Fig. I5), the double spireme (Fig. I7), and the characteristic forms of the gemini (Fig. I9). Chromosome-formation is preceded by an arrangement of the spireme into loops (Fig. I8) corresponding to the second contraction phase of other forms.

Eight chromosomes are present in the first mitosis (Figs. 20, 22) and four throughout the second and third (Figs. 25, 26, 29, 30). The pairing of the chromosomes which are to pass to different nuclei in brachymeiosis thus takes place, as in Humaria gramulata, at an early stage. In Peziza vesiculosa (8), another species in which the reduced number of chromosomes is apparent on the homotype spindle, a contraction stage was recognized both in the second and third prophase. This was regarded as representing the moment of association of the allelomorphs, and it was suggested that their union did not endure through the resting-stage, since a contraction (and presumably a pairing of the chromosomes) took place in the third as well as in the second prophase. In Ascobolus furfuraceus the prophases of the third division are readily studied, and it appears to us that here also the stages represented in Figs. 27 and 28 are best compared to the so-called first contraction of meiosis.

In the majority of Discomycetes examined, either in the course of this investigation or previously, the nuclear area is well marked, and is bounded,

of chromosomes in the later divisions in the ascus is at least as well authenticated as the chromosome number in the smaller nuclei of the ascogenous hyphae. There thus remains a fusion in the ascus and a brachymeiotic reduction, the latter a process nowhere associated with sexual fusion. If this be the case our present specimens of $H$. gramulata have progressed a stage further than other investigated forms in the loss of a sexual process. 
even at a late stage of mitosis, by a more or less definite line on which the centrosomes lie. In Ascobolus furfuraceus, however, the nuclear area, especially in the third division, is ill-defined and shades off gradually into the cytoplasm, and the spindle often lies to one side of or partially outside it (Fig. 30). This arrangement brings the centrosome nearer the centre of the dense mass of cytoplasm which constitutes the aster (cf. Fig. 22), and it also affects the relative distribution of the vacuoles and nuclei.

After the third division the cytoplasm is traversed by irregular series of vacuoles (Fig. $3^{2}$ ), which may be termed lines of cleavage. These play an important part in the delimitation of the spore, or rather in the segregation of the masses of spore-plasm. During spore-formation, as during karyokinesis, the cytoplasm near the centrosome takes at first a deeper stain than that which is more remote (Fig. 3I). As development proceeds this dense area extends, and the impression is given of an outward flow of some substance which emanates from the centrosome and is capable of producing alterations in the cytoplasm. It has already been suggested (9) that this substance is not improbably an enzyme. The difference between Ascobolus and the forms hitherto investigated lies in the much more important part here played by the vacuolate areas which we have termed lines of cleavage. Such lines no doubt originate at the nuclear areas, but we think it not unlikely that their further development is the result of new tensions set up in the cytoplasm by the changes going on around the centrosome. In the forms we have studied the astral rays and the limiting layer of the spore in its early stages are alike less definite than those illustrated by Faull (6).

As development proceeds the dense mass around the centrosome and nucleus becomes more regular, and is bounded by a definite line (Figs. 35, 36), while a similar membrane limits the neighbouring epiplasm. Between the two is a clear space related to the old lines of cleavage, and its boundaries both towards the spore and towards the epiplasm may well be such ectoplasmic layers as delimit an ordinary vacuole. This interpretation is somewhat remote from that given by Harper, though we indorse his conclusion that the aster plays an essential part in spore-formation. In Ascobolus the wall of the mature spore is of great thickness, and this fact may be related to the wide vacuolate area which separates the two limiting membranes at an earlier stage.

Divisions in the ascogenous hypha (Fig. I4) were several times observed in Ascobolus, but the cytoplasm is dense and contains various granules, and examples clear enough to allow a satisfactory determination of the chromosome number were not obtained. Our observations point to the occurrence of four chromosomes at this stage. This would indicate that pairing of chromosomes in fertilization takes place here as in Humaria gramulata. 


\section{LACHNEA STERCOREA.}

The development of Lachnea stercorea was investigated by one of us (7) in 1907. A trichogyne and antheridium are present, but no longer functional, and, as in Humaria gramulata, the female nuclei fuse in pairs in the ascogonium.

The nuclei of the ascus are not of great size, but the heterotype prophases are nevertheless remarkable for their clearness and delicacy. The first contraction takes place after the fusion in the ascus (Fig. 38), and is succeeded by the loosening out of a well-marked double spireme (Fig. 39); this subsequently draws itself up into about four loops (Figs. 40, 4I) in which the duplication of the chromatin thread may still be observed. Eventually four gemini separate (Fig. 42), contract (Fig. 43), and pass on to the spindle (Figs. 43, 44), where they undergo the usual separation into univalent chromosomes, and four of these pass to each pole (Fig. 45).

It seems to us very clear that in Lachnea stercorea the loops of the heterotype prophase each represent a bivalent chromosome, and that the separation on the spindle takes place transversely.

The homotype division is of the ordinary type ; the chromosomes are still four in number (Figs. 46, 47), and no 'contraction' phase has been observed to precede the appearance of the spindle. In the third metaphase four chromosomes are present (Fig. 48); they do not divide, and two only pass to each daughter-nucleus (Fig. 49). In these particulars brachymeiosis in Lachnea stercorea corresponds to the same process in $H$. rutilans (8), where also the double number of chromosomes is present throughout the second division and in the prophases of the third.

In studying the ascus divisions of this species we frequently observed the occurrence of two long and two short loops in the early meiotic stages (Figs. 40, 4I), and of two long and two short chromosomes in the later prophases (Figs. 42, 43), and in the heterotype spindle (Fig. 44). At this time the gemini, since the fusion in the ascus is complete, represent two sets of paired allelomorphs. Separation of those which came together in fertilization takes place in the first division, while the distribution of the allelomorphs of the asexual fusion is accomplished in brachymeiosis. In the telophase of the latter division (Fig. 49) a long and a short chromosome can, in favourable cases, be distinguished at the pole.

We were not prepared to attach importance to any of these cases separately, but the frequent recurrence of the long and short chromosomes, and of the long and short loops in the earlier meiotic stages seems tous not without significance. Moore and Arnold (14), investigating the meiotic phase in man and other animals, have found that the forms of the gemini are constant in all spermatocytes of a given species. Baumgärtner (1) also in two species of cricket finds recurrent differences in 
the forms of the chromosomes. These differences he regards as indications of the fact that each type of chromosome forms the physical basis of a different set of characters. Lachnea stercorea is an instance among plants of a corresponding arrangement.

The ascogenous hyphae (Fig. 37) in Lachnea are small, and we have not been able to count the chromosomes.

In spore-formation in Lachnea the lines of cleavage are not so much in evidence as in Ascobolus. The usual dense and presumably altered mass of cytoplasm is present around the centrosome (Fig. 50), and, as usual, it increases in size (Fig. 5I), and constitutes the spore-plasm. It is traversed and defined in Lachnea by astral rays which are finer but more numerous and better marked than in Ascobolus. Vacuoles corresponding to the lines of cleavage are, however, not without effect, and in the stage shown in Fig. $5^{2}$ a clear space surrounds the aster and perhaps helps to cut out the lower part of the spore.

\section{Discussion.}

The observations detailed above show that in each of the forms investigated two reduction-divisions take place. The first mitosis in the ascus has in every case the familiar characters of the heterotype division. and reasons have been elsewhere adduced (Fraser and Welsford (9)) for regarding this type of reduction as associated with fertilization or its equivalent. The second division follows rapidly on the first, and-at least in Humaria mutilans and Lachnea stercorea-is without special features ; it seems justifiable therefore to accept it as homotype, and as completing the longitudinal fission of the spireme initiated in the heterotype prophase.

The third division differs little from a vegetative mitosis, but in its telophase the number of chromosomes is seen to be half that present on the heterotype spindle, consequently the third division has been recognized as bringing about a second reduction, and has been termed brachymeiosis. This standpoint has recently been criticized by Strasburger (18); he thinks it unlikely that two reductions should take place in the ascus, holding it more probable that, as Claussen ${ }^{1}$ (3) suggests, there is only one fusion in the life-history of Ascomycetes. He doubts that reduction would take place in one division or without a contraction phase. It is, therefore, of interest that in some of the forms described both at this time and in a previous paper (9), the third division is initiated by a stage comparable to the 'first contraction' of meiosis. Where this occurs, the reduced number

${ }^{1}$ Claussen's view has recently received confirmation from Schikorra (17), who has seen male nuclei enter the ascogonium of Monascus but considers that their association with the female nuclei is of the nature of an approximation and not a fusion. Like Claussen he considers that the associated nuclei travel in pairs up the ascogenous hyphae and fuse in the ascus. He brings forward no evidence as to the reducing divisions in the ascus and his evidence with regard to the absence of fusions in the ascogonium is of course entirely negative. 
of chromosomes is apparent in the prophase as well as in the anaphase, the chromosomes having become paired at the beginning of the third division. In yet another species the pairing takes place in the second prophase, and when this happens, two divisions are concerned in brachymeiosis. In such cases the possibility is not excluded that the second reduction is accomplished in the homotype, and that the chromosomes of the second telophase as well as those of the third are actually univalent. Nevertheless such a state of affairs appears to us improbable, since the ordinary rôle of the homotype is clearly to separate the products of a longitudinal fission occurring in the heterotype spireme. If, in certain cases, the second division is brachymeiotic, this separation must be delayed till the third division, and there seems no sufficient reason to suppose so radical a divergence in the reduction processes of closely related forms.

A yet more essential difference between meiosis and brachymeiosis lies in the occurrence of a second contraction in meiotic reduction and its absence in the simpler process. If this phase be indeed the moment of interchange of material between the allelomorphs (Fraser and Welsford (9)) its absence in brachymeiosis may well indicate that this type of reduction and the corresponding asexual fusion have little effect on the forms in which they occur. Where the chromosomes are paired throughout the second division and in the prophases of the third, as in Ascobolus furfuraceus, another opportunity for the transfer of material may exist, but even this is absent in Lachnea stercorea and Humaria rutilans, where after meiosis the allelomorphs are at no time visibly associated.

The fact that reduction in the number of chromosomes occurs after meiosis is complete has received confirmation not only from the work of Maire (13) and Guillermond (11), but more recently from Dangeard (4), who can scarcely be regarded as biassed in favour of a series of events which implies two fusions. He has recorded the numerical changes in question in Ascobolus furfuraceus, and is of opinion that they take place also in Pyronema confluens. In neither form, it must be added, has Dangeard found a sexual union in the ascogonium, but he has confined his investigations to the occurrence of a male organ, and has ignored the possibility of such a fusion in pairs of ascogonial nuclei as takes place in Humaria granulata.

The evidence on this question has been discussed in earlier papers; it seems unnecessary to enter again into an enumeration of the species in which two successive fusions have been seen.

\section{The Pairing of the Allelomorphs.}

Recent investigation has dealt extensively with the method in which the premeiotic chromosomes conjugate to form the gemini of the heterotype 
prophase. According to a considerable body of workers the chromosomes become joined end to end, and the early duplication of the spireme is due to fission; this view was elaborated by Farmer and Moore (5) in 1905 , and has again lately received confirmation in the work of R. R. Gates (10). Gates finds the premeiotic chromosomes of Oenothera rubrinervis arranged in linear series and separated by delicate threads of linin. From this spireme the chromosomes break off in pairs, each pair forming one of the gemini which are thus half as numerous as the chromatin masses on the spireme.

Other investigators, including Strasburger, Grégoire, and their pupils have regarded the paternal and maternal spiremes as arranged side by side in parallel lines; the chromosomes are held to conjugate laterally, and to undergo a more or less intimate union during the so-called synaptic or first contraction. Notably Overton (15), studying the pollen mothercells of Thalictrum purpurascens and some other species, has described a series of double bodies lying along the spireme; he regards these as gemini each made up of two premeiotic chromosomes lying side by side.

It is irresistible to compare with such bodies the chromosomes figured by Gates, and at first sight they appear to be strictly comparable, but it is important that while Gates's structures are said to be twice as numerous as the chromosomes of the homotype telophase, Overton's are described as equal to these in number. In other words, the heterotype prophase of Oenothera shows $2 n$ chromosomes arranged in linear series and separating two and two, while in Thalictrum there appear to be two spiremes with $n$ chromosomes each, and these lie side by side. If both these accounts be correct it must be inferred that the chromosomes become associated in the one case end to end, and in the other laterally. Gates has further shown that in Oenothera hybrids the union of fourteen and seven chromosomes in fertilization gives rise to ten or eleven 'gemini' $\left(\frac{\mathrm{I} 4+7}{2}\right)$ in the heterotype prophase. He points out that this could scarcely occur if the paternal and maternal spiremes lay side by side. On the other hand in Drosera (Rosenberg (16)) a form with twenty chromosomes crossed by one with ten gives thirty in the sporophyte, and twenty, ten large and ten small $\left(\frac{10+10}{2}+10^{\prime}\right)$, in meiosis. This is not inconsistent with lateral union, but there seems no reason why it should not equally be the result of association end to end, and it is suggestive in this connexion that the bivalent chromosomes are of greater length than the others.

In the Discomycetes hitherto investigated the chromosomes were found to become paired end to end, and our present studies confirm this conclusion. In Mildews, on the other hand, Harper (12) has shown that the chromosomes are recognizable throughout the resting-stages, and remain 
attached by one end to the centrosome. On nuclear fusion the centrosomes unite, and the chromosomes lie parallel for a time, and in that position fuse in pairs. Harper's studies relate primarily to the fusion in the ascus.

It is remarkable that in Mildews nuclear fusion, whether sexual or asexual, appears to be followed directly by the pairing of the chromosomes ; thus the gametophytic number of chromosomes in Phyllactinia (Harper 12)) is eight, yet eight appear in the ascogenous hyphae after fertilization and eight again in the ascus between the subsequent asexual fusion and meiosis.

Similarly in Humaria granulata union of the chromosomes takes place after fertilization; we have unfortunately no evidence to bring forward as to the method by which this is accomplished, but the association is so intimate that on the spindle of the ascogenous hypha the double nature of the pairs cannot be detected. In Phyllactinia a pairing of the already bivalent chromosomes to form quadrivalent bodies follows the fusion in the ascus; in $H$. gramulata this does not occur, but the chromosomes of the asexual fusion remain apart till the heterotype division is complete: they then pair in the prophases of the homotype.

Union of the chromosomes brought together by the fusion in the ascus takes place at a corresponding stage in Ascobolus furfuraceus and Peziza vesiculosa, but in Otidea aurantia it is delayed till the beginning of the third division. In Lachnea stercorea, as in Humaria rutilans, no visible pairing of the chromosomes occurs in connexion with brachymeiosis.

The accompanying Text-figure shows diagrammatically the relation between the forms described in this paper and some of those previously studied. For the sake of uniformity we have represented the minimum number of chromosomes as two throughout.

There is thus a remarkable lack of uniformity in the extent of chromosome union which precedes brachymeiosis. This may be due to the fact that the two nuclei which fuse in the ascus are always the products of development of a single spore-or at most, if a functional antheridium develop on a different mycelium from the ascogonium, of a single pair of spores-and they are often much more closely related. Moreover, they have been subjected to the same environment, and it appears therefore justifiable to suppose them identical. Under these conditions interchange of material between the chromosomes can have little effect, and the intimacy or duration of their union seems to be without importance.

\section{SPORE-FORMATION.}

The divergent views held on the method of spore-formation have been enumerated in earlier papers $(8,9)$. In this connexion the chief interest of our present investigation lies in the important part played by the vacuolate 
areas or line of cleavage in Ascobolus. We find here a differentiation into dense and vacuolate areas such as is described by Faull (6), though we find also that the centrosome and aster are essential to the development of at least the denser portions. For Neotiella albocincta, Faull describes the spore as delimited by a 'curved hyaline line' which may well correspond to our line of cleavage in Fig. $3^{8}$ or 34 . Later he distinguishes two plasma membranes, one of which bounds the spore-plasm, and the other the epiplasm in which the spore lies. This also accords with our observations. But while Faull does not figure an aster after spore-formation has begun, our investigations lead to the conclusion that the changes observed in the cytoplasm are due to a reaction which is set up in the neighbourhood of the

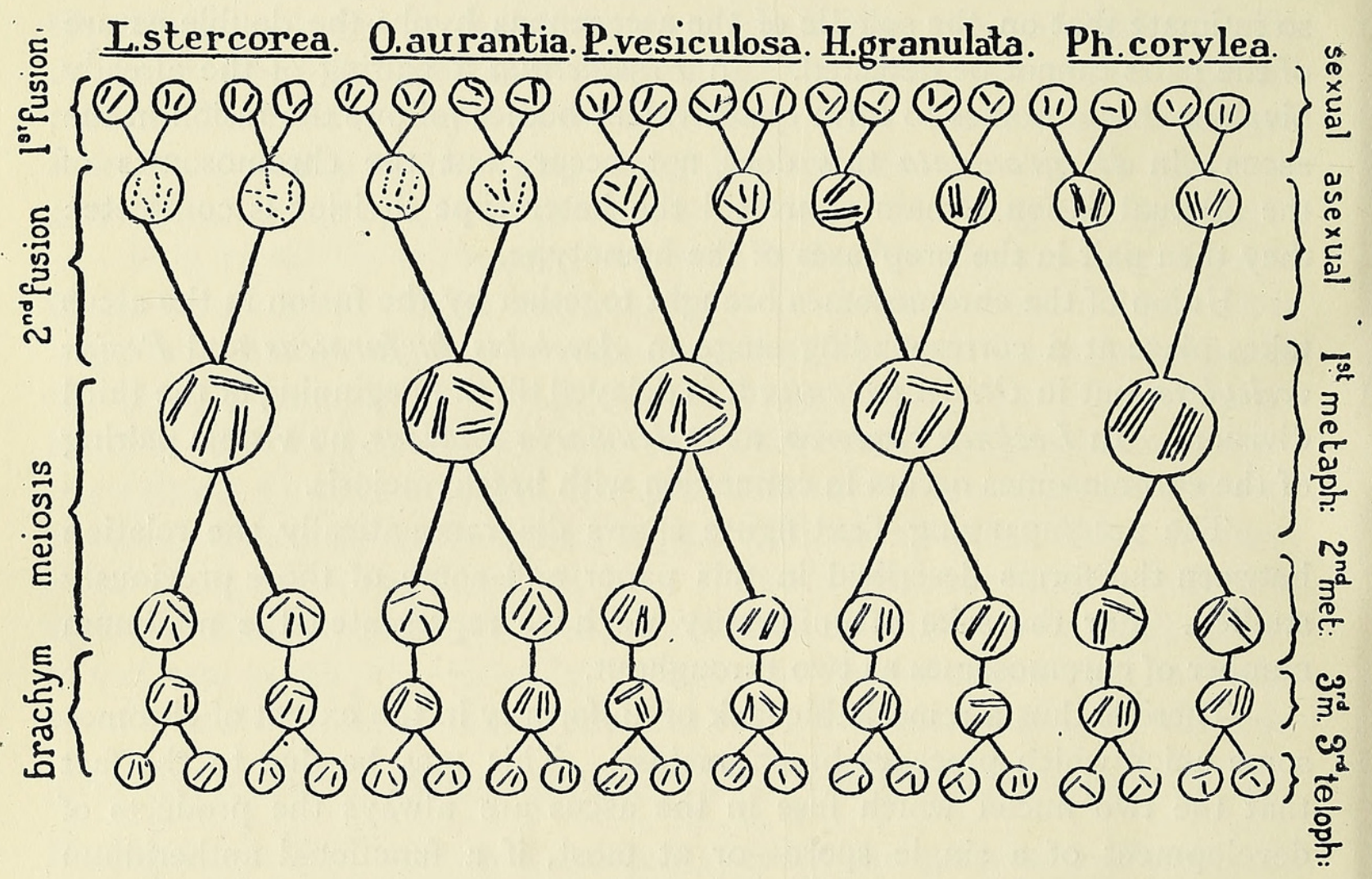

centrosome, and which, by producing new tensions in the ascus, eventually gives rise to the lines of cleavage themselves.

In Ascobolis furfuraceus it may be suggested that the altered substance streaming out from the centrosome runs through or forms part of the hyaloplasm, and leaves the cytoplasmic reticulum comparatively unaltered; the same is perhaps the case in Faull's species. In Lachnea stercorea, on the other hand, the astral radiations are well marked, and this species, which appears to us quite comparable to Ascobolus, thus approach the forms studied by Harper. We have, however, obtained no evidence of a lateral fusion of astral rays to form a membrane such as he describes, but we hold rather that the rays indicate the direction of flow of altered 
substance from the centrosome. It was suggested in an earlier paper (9) that such changes might be due to the action of an enzyme.

There appears to exist a somewhat complete gradation of forms from those in which the activity of the centrosome is the only force at work to those where vacuoles delimit-or help to delimit-the spore. In the latter cases we are inclined to regard the changes around the centrosome as ultimately responsible also for the vacuoles.

\section{SUMmary.}

I. The divisions in the ascus have been investigated in Humaria gramulata, Ascobolus furfuraceus, and Lachnea stercorea; in each of these species previous investigations showed that a pseudapogamous fusion occurs in the ascogonium, and a subsequent asexual fusion in the ascus.

2. In each the first division in the ascus is heterotype, the second homotype, and the third brachymeiotic. Two reductions in the chromosome number thus occur in the ascus of each species, and afford independent confirmation of the two successive fusions previously described.

3. The number of chromosomes in the first division in the ascus is eight in Humaria and Ascobolus, and four in Lachnea. After brachymeiosis is complete there are four chromosomes in Humaria and Ascobolus, and in Lachnea two.

4. Pairing of the chromosomes which are to separate in brachymeiosis takes place in the second prophase in Humaria and Ascobolus, but does not occur in Lachnea.

5. In Humaria the chromosomes brought together in fertilization are found to be paired in the division preceding meiosis.

6. The meiotic prophases were studied in some detail in Lachnea; the parts of the bivalent chromosome are united end to end, and separate transversely.

7. In the first ascus division in Lachnea two long chromosomes and two short ones may be constantly recognized, and in the third telophase, after brachymeiosis is complete, one long and one short chromosome.

8. The delimitation of the spore in Lachnea depends on altered substance flowing out from the centrosome. This is less evident in Ascobolus where vacuoles play an important part in spore-formation. 


\section{LIST OF PAPERS.}

1. BAUmgärtner, W. J.: Some new Evidence for the Individuality of the Chromosomes. Biol. Bull., viii, 1904, p. 1 .

2. Blackman, V. H., and Fraser, H. C. I.: On the Sexuality and Development of the Ascocarp in Humaria granulata, Quel. Proc. Roy. Soc. London, B., lxxvii, I906, p. 354.

3. Claussen, P.: Zur Kenntnis der Kernverhältnisse von Pyronema confluens. Ber. der deut. bot. Gesellsch., xxv, 1907, p. $5^{86 .}$

4. Dangeard, P.: Sur le développement du périthèce chez les Ascomycètes. Le Botaniste, $\mathrm{X}, \mathrm{I} 907$, p. I.

5. Farmer, J. B., and Moore, J. E. S.: On the Meiotic Phase (Reducing Division) in Animals and Plants. Q. J. M. S., cxcii, I905, p. 489.

6. Faull, J. H. : Development of the Ascus and Spore-formation in Ascomycetes. Proc. Boston Soc. Nat. Hist., xxxii, 1905 , p. 77 .

7. Fraser, H. C. I. : On the Sexuality and Development of the Ascocarp in Lachnea stercorea, Pers. Ann. Bot., xxi, 1907, p. 349 .

8. : Contributions to the Cytology of Humaria rutilans. Ann. Bot., xxii, I908, p. 35 .

9. - and Welsford, E. J.: Further contributions to the Cytology of the Ascomycetes. Ann. Bot., xxii, 1908, p. 465.

10. Gates, R. R. : A Study of Reduction in Oenothera rubrinervis. Bot. Gaz., xlvi, I908, p. I.

11. Guillermond, M. A.: Remarques sur la karyokinèse des Ascomycètes. Ann. Mycol., iii, 1905, p. 344 .

12. HARPER, R. A.: Sexual Reproduction and the Organization of the Nucleus in certain Mildews. Publ. Carnegie Inst. Washington, No. 37,1905 , p. I.

13. MaIre, R.: Recherches cytologiques sur quelques Ascomycètes. Ann. Mycol., iii, 1905, p. I23.

14. Moore, J. E. S., and Arnold, G.: On the Existence of Permanent Forms among Chromosomes of the First Meiotic Division in certain Animals. Proc. Roy. Soc. London, B., lxxvii, I906, p. $5^{6} 3$.

15. Overton, J. B.: Organization of Nuclei in Pollen Mother-Cells. Ann. Bot., xxiii, r9o9, p. I9.

16. Rosenberg, O.: Tetradenteilung eines Drosera-Bastardes. Ber. d. deut. bot. Gesellsch., xxii, I 904, p. 47.

17. Schikorra, W.: Ủber die Entwickelungsgeschichte von Monascus. Zeitschrift für Botanik, i, I909, p. 379 .

18. Strasburger, E.: Zeitpunkt der Bestimmung der Geschlechts, Apogamie, Parthenogenesis und Reduktionsteilung. Histologische Beiträge, vii, p. Ior.

19. Welsford, E. J.: Fertilization in Ascobolus furfuraceus. New Phyt., vi, 1907, p. I 36.

\section{EXPLANATION OF PLATES XXXIX AND XL.}

Illustrating Dr. Fraser's and Mr. Brooks's Paper on the Cytology of the Ascus.

\section{Humaria gramulata.}

Fig. I. Metaphase in ascogenous hypha. $\times 1900$.

Fig. 2. Early anaphase in ascogenous hypha. $\times 1900$.

Fig. 3. Telophase in ascogenous hypha. $\times 1900$.

Fig. 4. Definitive nucleus of ascus, first 'contraction'. $\times 1900$.

Fig. 5. Definitive nucleus of ascus, second 'contraction'. $\times \mathbf{I g 0 0 .}$

Fig. 6. Gemini of heterotype prophase. $\times 1900$.

Fig. 7. Gemini at time of spindle formation. $\times 1900$. 
Fig. 8. First division in ascus, equatorial plate showing eight chromosomes. $\times 1900$.

Fig. 9. First anaphase. $\times 1900$.

Fig. I0. Second metaphase. $\times 1900$.

Fig. 11. Second anaphase. $\times 1900$.

Fig. I 2. Third metaphase. $\times$ I900.

Fig. I3. Third anaphase, four chromosomes passing to each pole. $\times 1900$.

\section{Ascobolus furfuraceus.}

Fig. 14. Mitosis in ascogenous hypha. $\times 1900$.

Fig. I 5. Definitive nucleus of ascus, stage of first 'contraction'. $\times 1900$.

Fig. 16. Later stage of same; spireme beginning to spread through nuclear area. $\times 1900$.

Fig. 17. Definitive nucleus of ascus; duplication of spireme. $\times$ Igoo.

Fig. 18. Definitive nucleus of ascus; formation of loops of second contraction phase. $\times$ I900.

Fig. 19. Gemini of heterotype prophase. $\times 1900$.

Fig. 20. Later stage in development of spindle of first mitosis; eight chromosomes. $\times 1900$.

Fig. 21. First metaphase; gemini on spindle. $\times 1900$.

Fig. 22. First anaphase. $\times 1900$.

Fig. 23. First telophase; around the centrosome is a dense area separated by a vacuolate space from the rest of the cytoplasm. $\times 1900$.

Fig. 24. Second prophase; chromatin lying to one side of the nuclear area; an unusually large ascus. $\times 1900$.

Fig. 25. Second metaphase. $\times 1900$.

Fig. 26. Second anaphase. $\times 1900$.

Fig. 27. Third prophase; lateral aggregation of chromatin. $\times 1900$.

Fig. 28. Later stage of same; from ascus visible in same field of microscope as that of Fig. $27 . \times 1900$.

Fig. 29. Third metaphase. $\times 1900$.

Fig. 30 . Third anaphase; four chromosomes passing to each plate. $\times$ I900.

Fig. 3I. Third mitosis; late telophase showing nuclear beak, centrosome, and aster. $\quad \times 1900$.

Fig. 32. Later stage; development of lines of cleavage in connexion with vacuoles in cytoplasm. $\times 1900$.

Fig. 33. Same; later stage. $\times 1900$.

Figs. 34, 35. Same; still later stages. $\times 1900$.

Fig. 36. Young spores in ascus; inner spore wall is nearly complete; outer wall is defined by limiting layer of cytoplasm beyond old line of cleavage. $\times 1900$.

\section{Lachnea stercorea.}

Fig. 37. Division in ascogenous hypha. $\times 1900$.

Fig. 38. Definitive nucleus of ascus; stage of first 'contraction'. $\times 1900$.

Fig. 39. Definitive nucleus of ascus; longitudinally split spireme. $\times 1900$.

Fig. 40. Second contraction; the four loops show longitudinal fission in places. $\times 1900$.

Fig. 4I. Later stage of same; two loops appear long and two short. $\times 1900$.

Fig. 42. First prophase; four gemini. $\times 1900$.

Fig. 43. First prophase; passage of contracted gemini on to spindle. $\times 1900$.

Fig. 44. First metaphase. $\times 1900$.

Fig. 45. First anaphase; four chromosomes travelling to each pole. $\times 1900$.

Fig. 46. Second metaphase; section parallel to long axis of ascus. $\times 1900$.

Fig. 47. Second anaphase; ascus is cut obliquely so that nuclear area is viewed at about right angles to that of Fig. 46. $\times 1900$.

Fig. 48. Third metaphase; one of the nuclei is shown in polar view. $\times$ I 900.

Fig. 49. Third telophase; in the second nuclens from the top one of the chromosomes appears shorter than the other. $\times 1900$.

Fig. 50. Early stage of spore formation, showing nuclear beak centrosome, radiations, and near one of the asters, a vacuolate area. $\times 1900$.

Fig. 5 I. Same; more advanced stage. $\times 1900$.

Fig. 52. Delimitation of spores; vacuolate lines, comparable to the lines of cleavage in Ascobolus, are present between the aster and the epiplasm. $\times 1900$. 

Annals of Botany
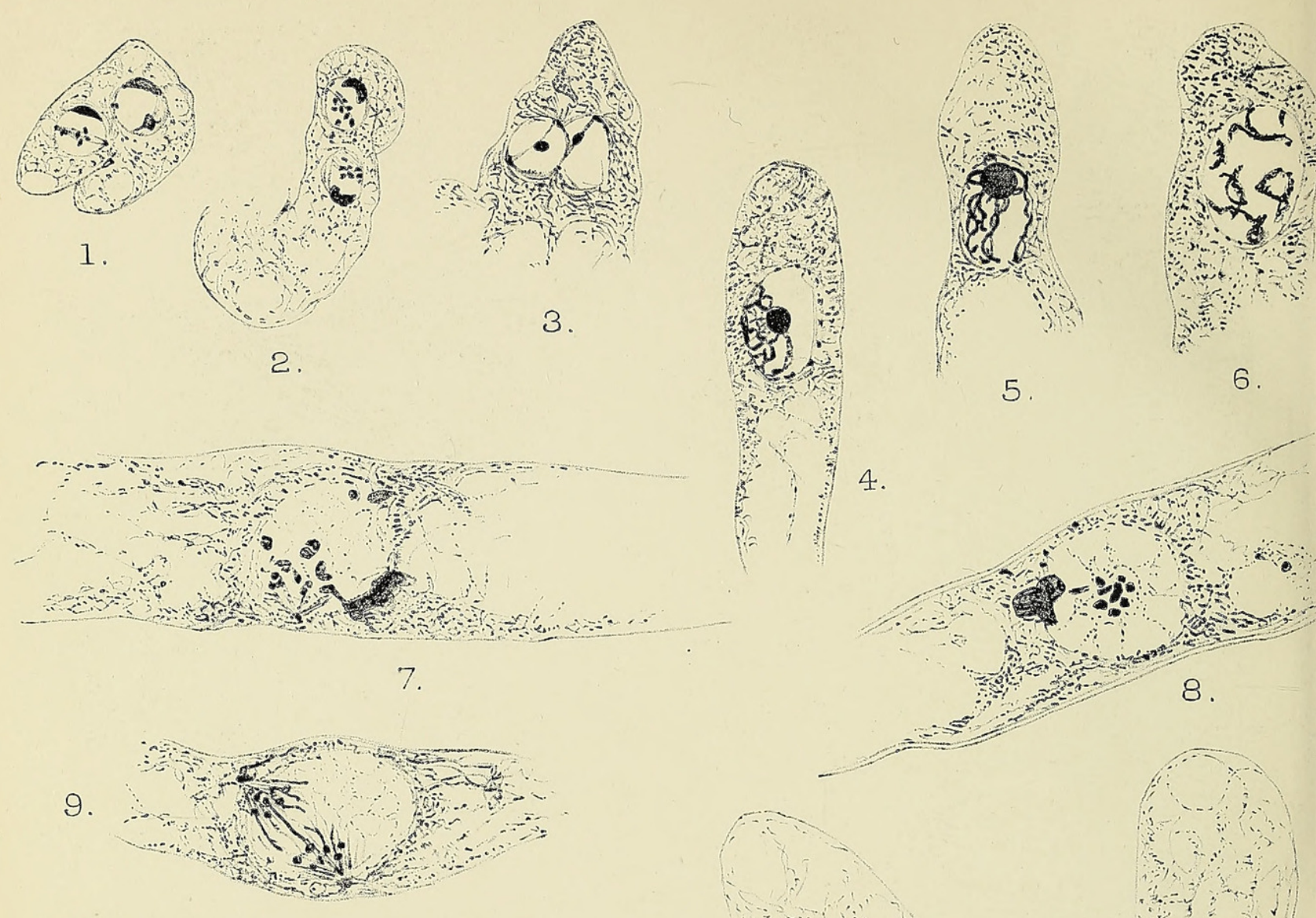

9
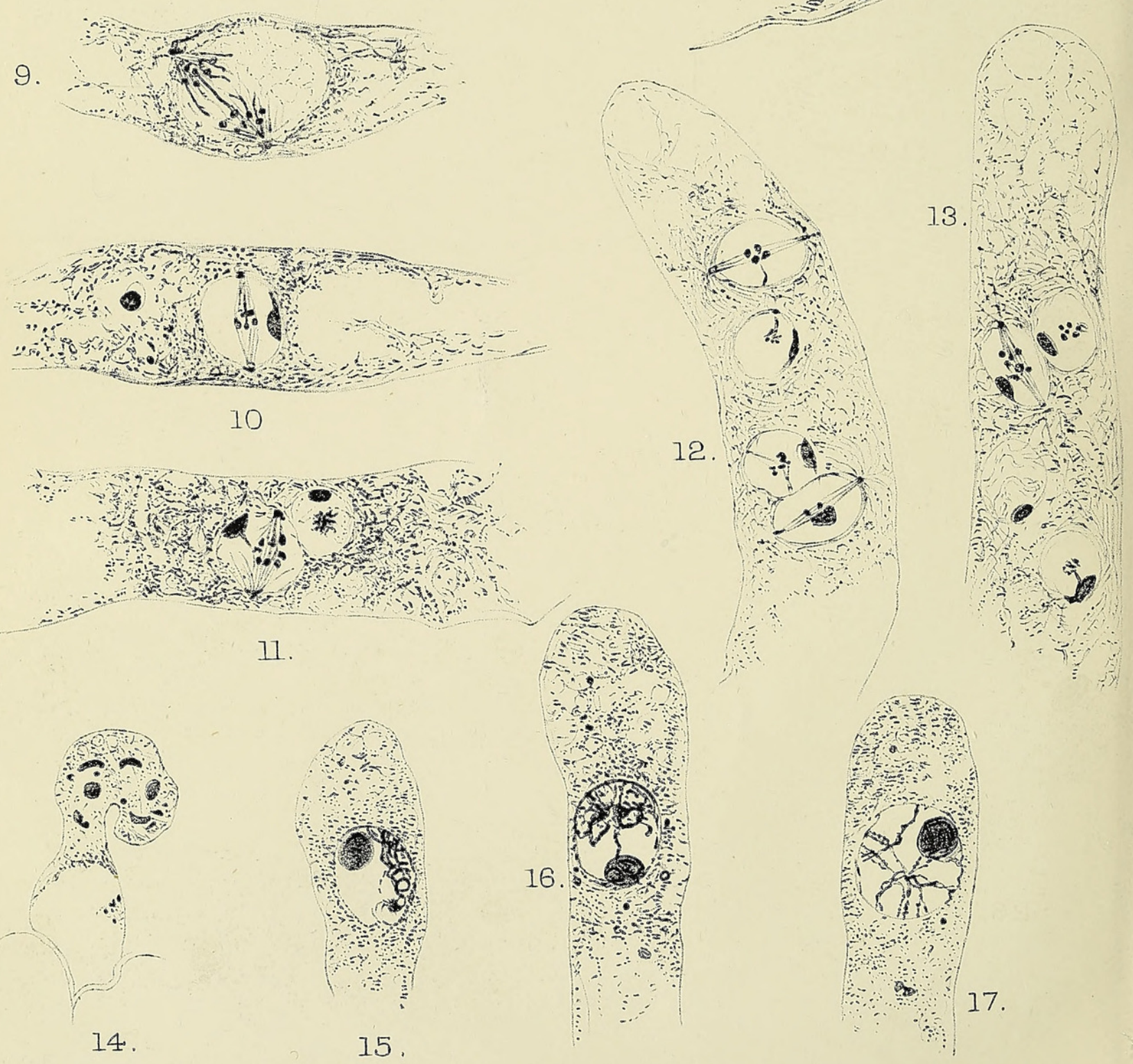

FRASER AND BROOKS - HUMARIA AND ASCOBOLUS. 
Vol.XXIII. Pl.XXXIX.
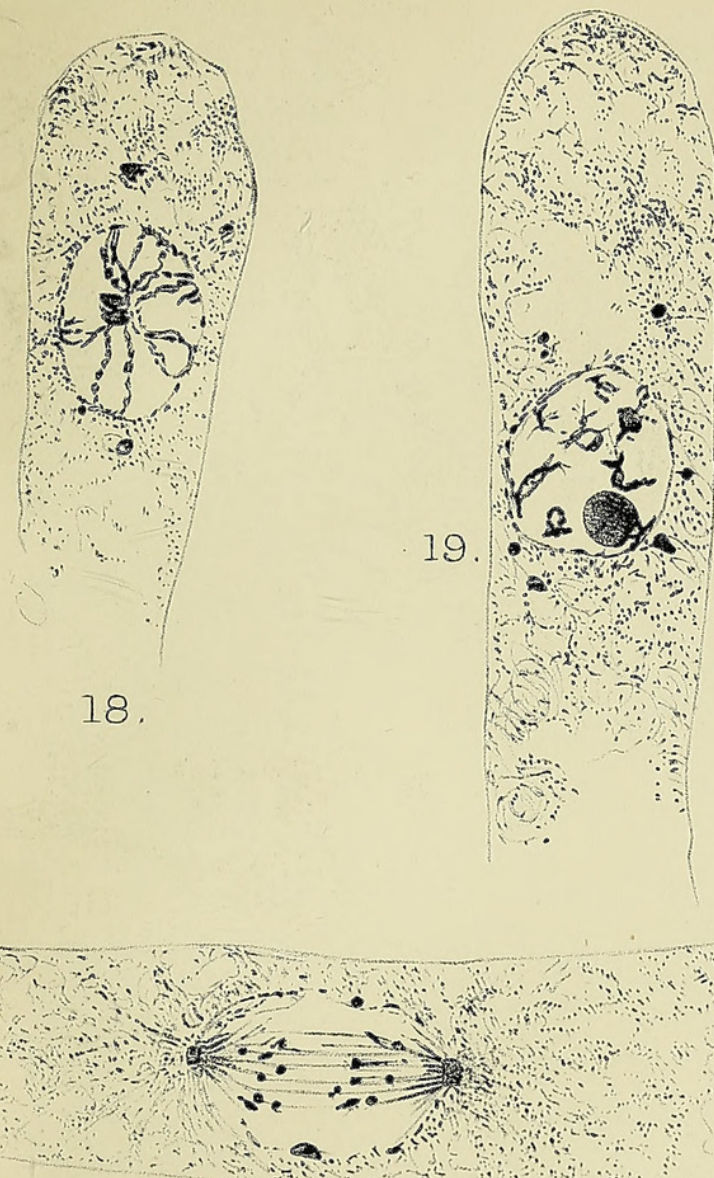

22

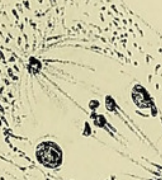

2. $\frac{5}{4}$

i. - 0 -

25.

(.)

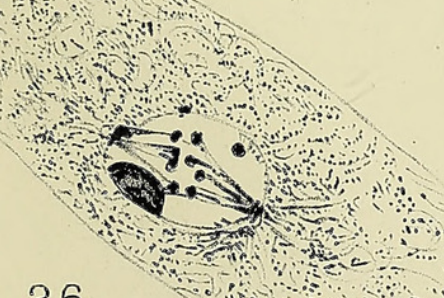

26

a

27.

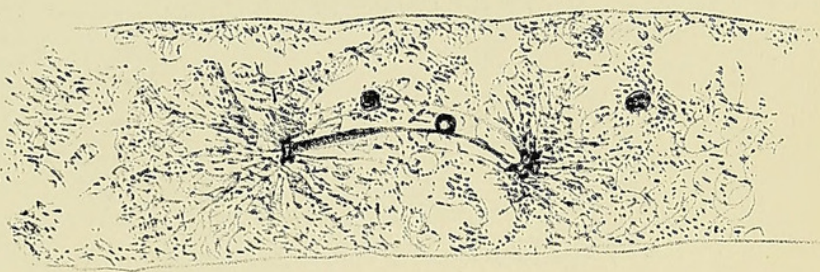

23.

\section{0.}

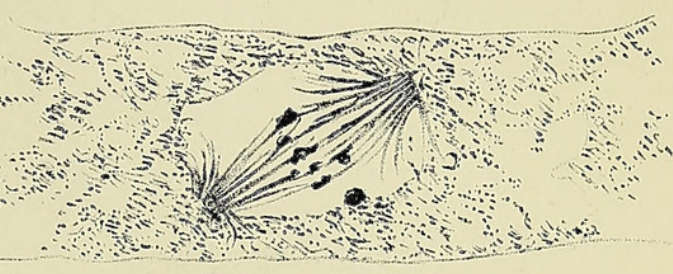

21.

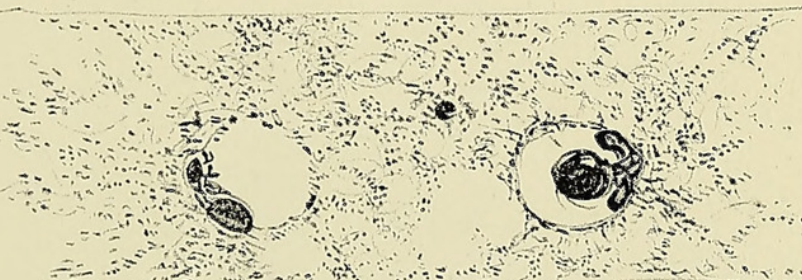

24. 
Annals of Botany
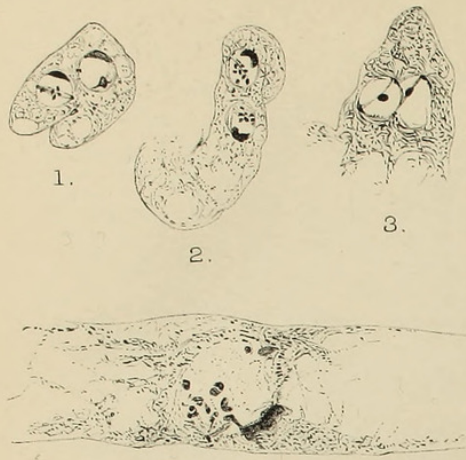

9.

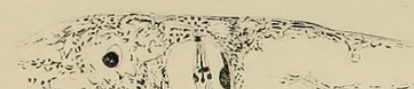

Thes to

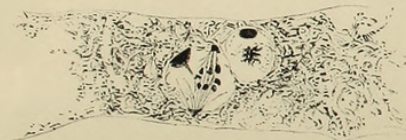

11.

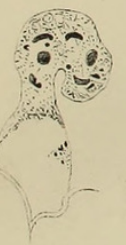

14.

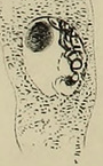

15.

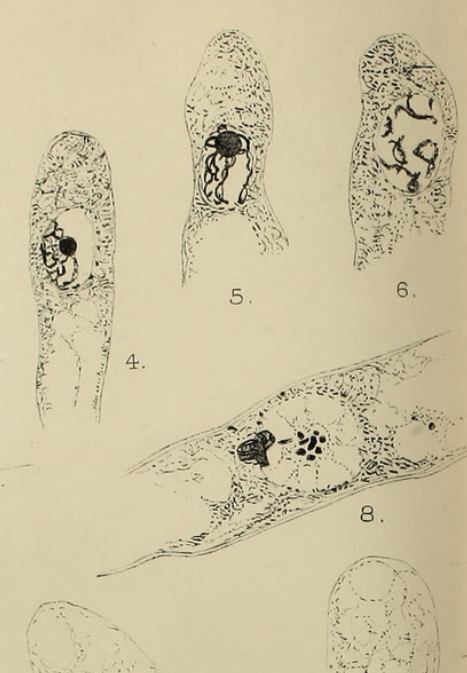

$\because$

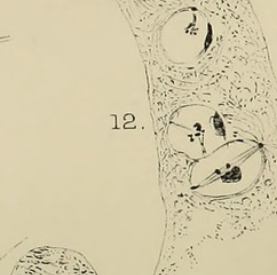

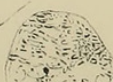

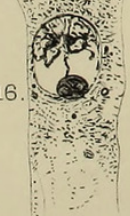

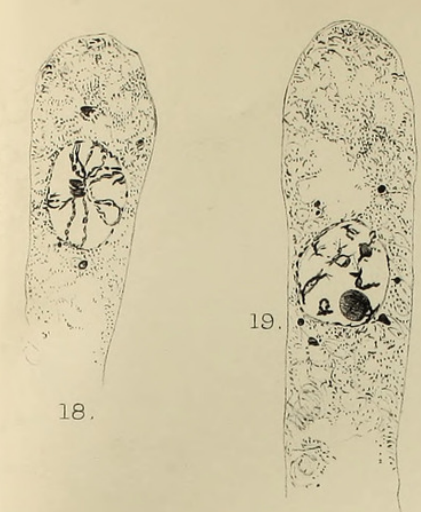
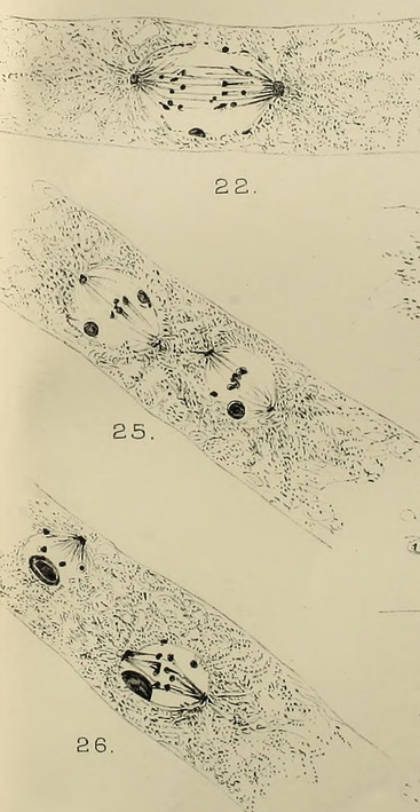

Vol.XXIII.PL.XXXIX.

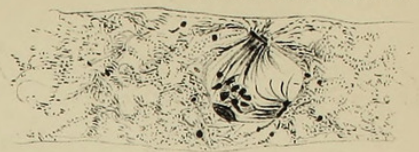

20.

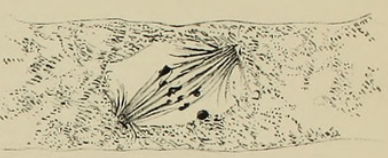

21 .

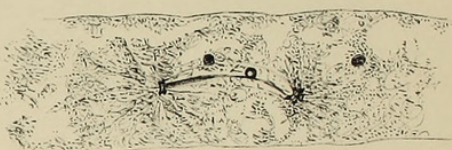

23.

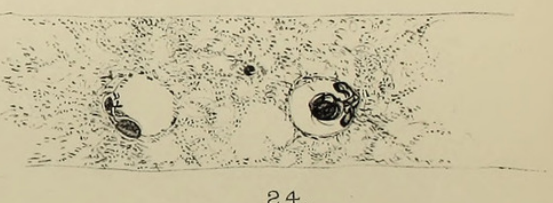

a

(6) $80^{2}$ 
Annals of Botany

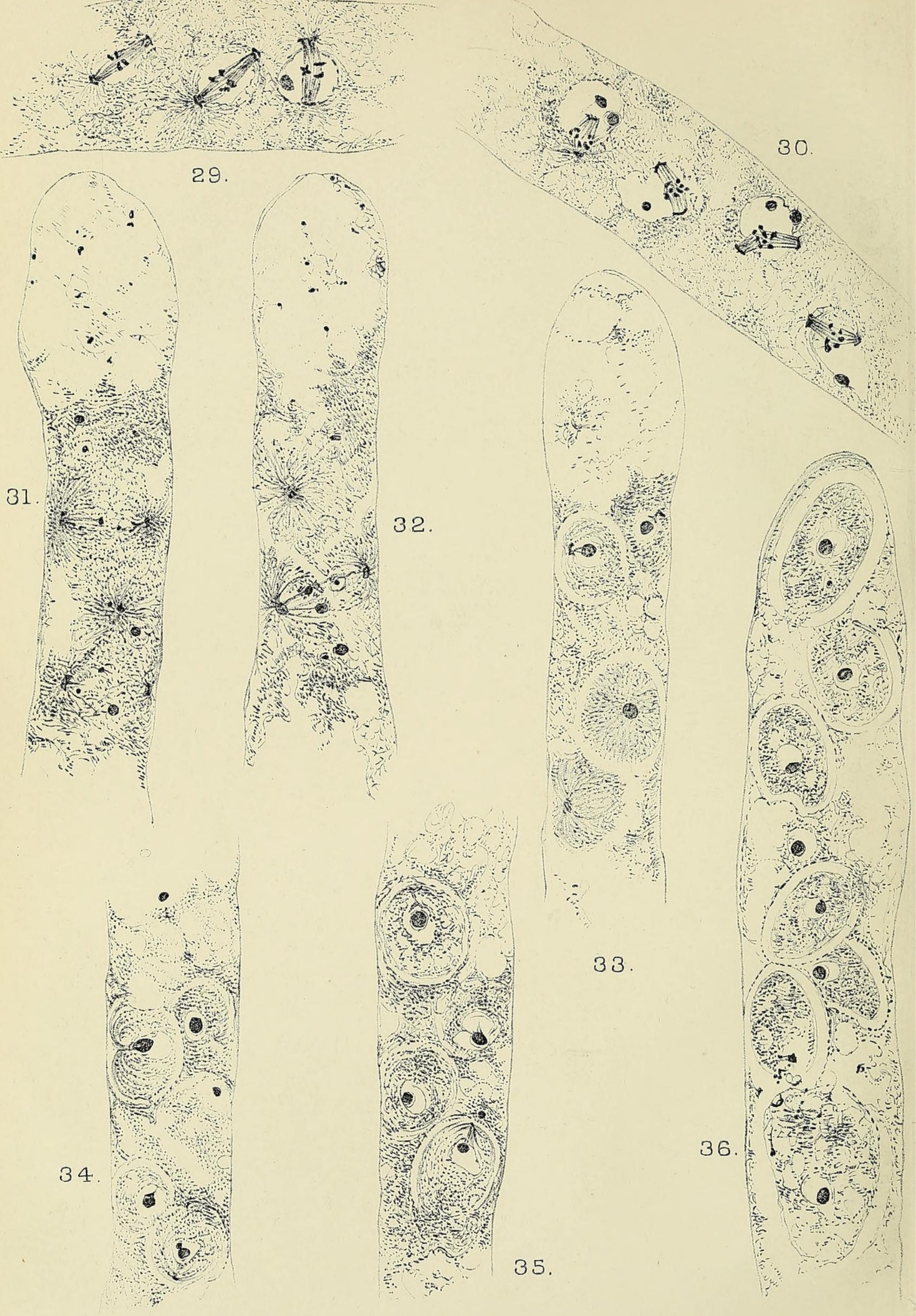

FRASER AND BROOKS - ASCOBOLUS AND LACHNEA. 
Vol. XXIII. PL.XZ.
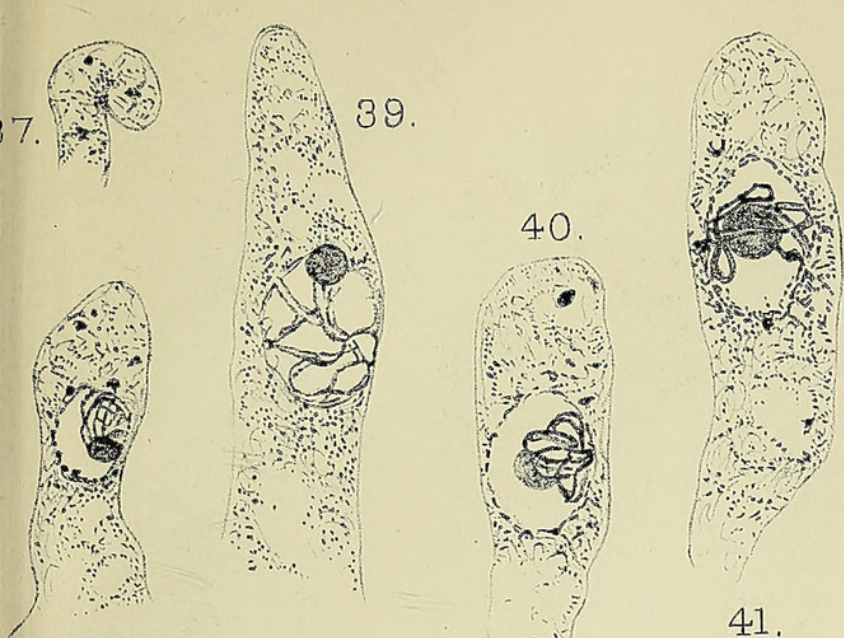

38.

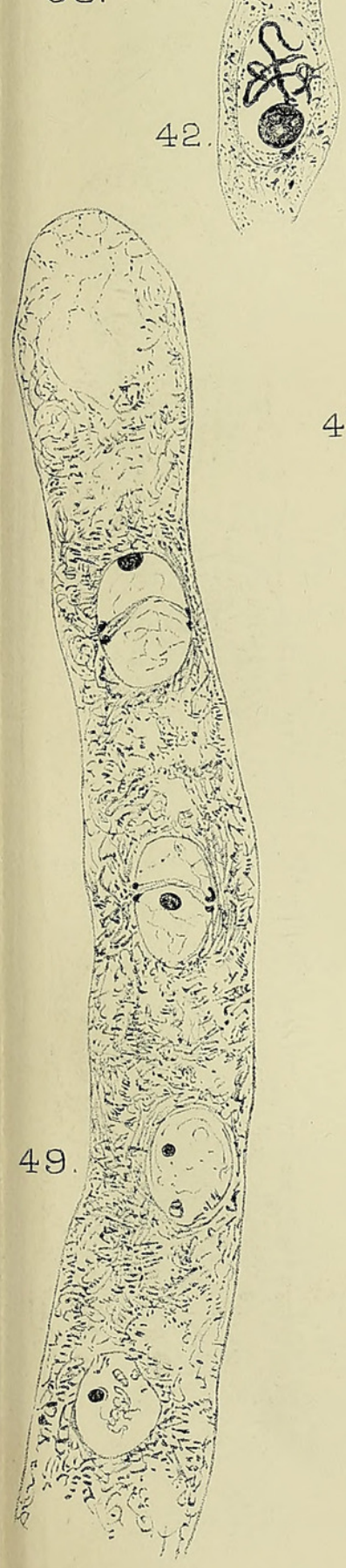

41.
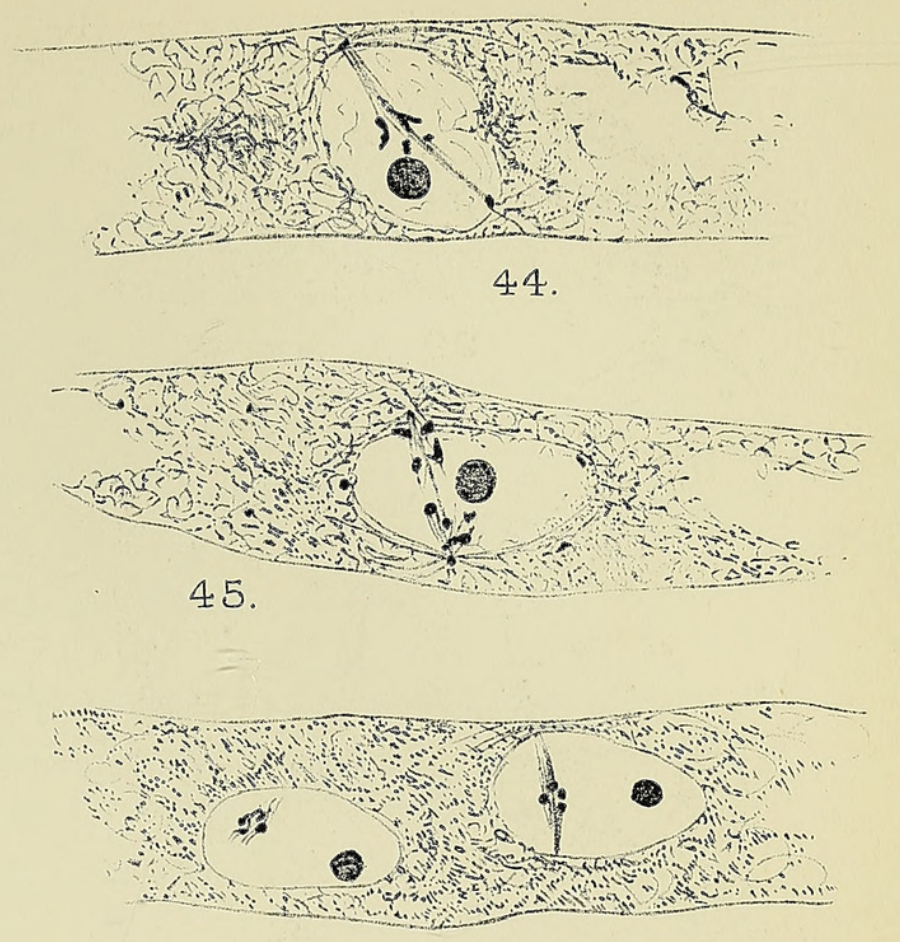

46.

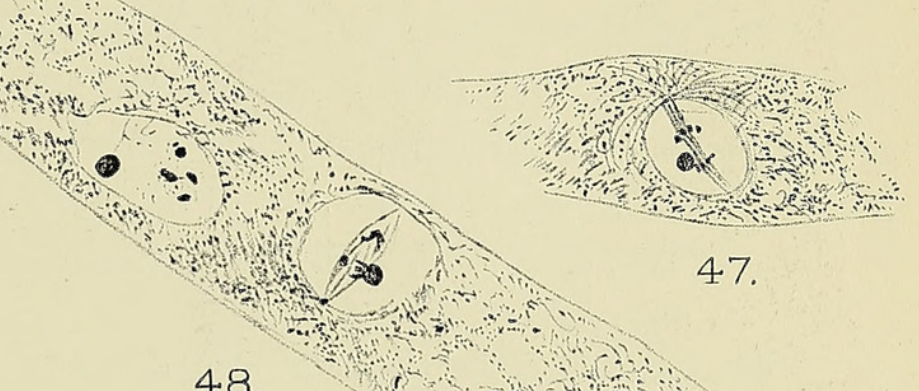

48.

$(1)$

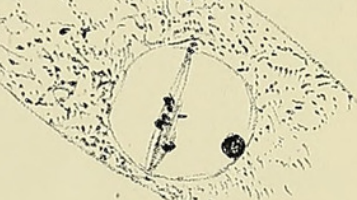

(1)

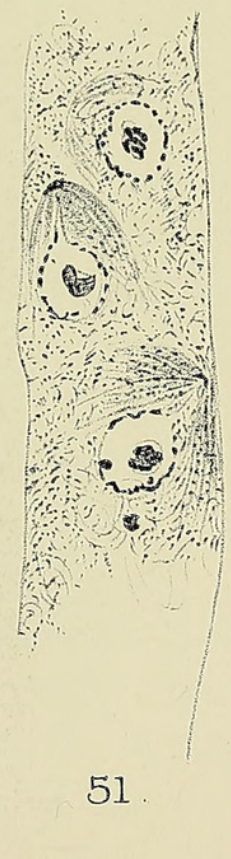

\section{(1)}

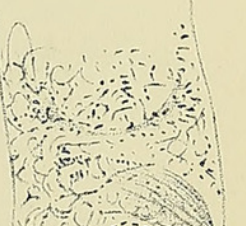

$(7)$

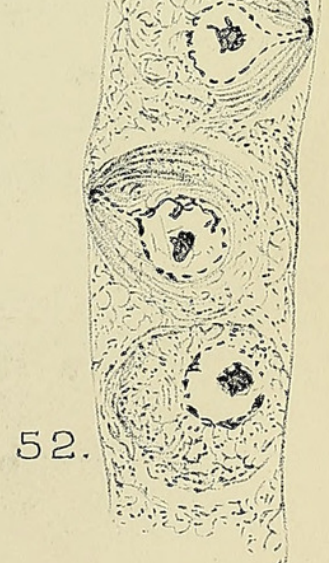

50.

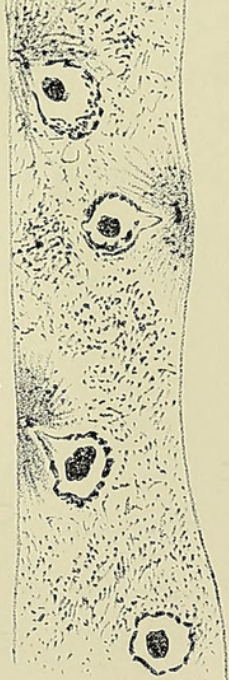




\section{$2 \mathrm{BHL}$ Biodiversity Heritage Library}

Gwynne-Vaughan, H. C. I. and Brooks, W. E. St. John. 1909. "Further studies on the cytology of the ascus." Annals of botany 23, 537-550.

https://doi.org/10.1093/oxfordjournals.aob.a089237.

View This Item Online: https://www.biodiversitylibrary.org/item/236540

DOI: https://doi.org/10.1093/oxfordjournals.aob.a089237

Permalink: https://www.biodiversitylibrary.org/partpdf/318972

\section{Holding Institution}

Smithsonian Libraries

\section{Sponsored by}

Biodiversity Heritage Library

\section{Copyright \& Reuse}

Copyright Status: Not in copyright. The BHL knows of no copyright restrictions on this item.

This document was created from content at the Biodiversity Heritage Library, the world's largest open access digital library for biodiversity literature and archives. Visit BHL at https://www.biodiversitylibrary.org. 